\title{
Issues for CEOs of Water Utilities with the Implementation of Australian Water Laws
}

\author{
Jennifer McKay \\ Director, Center for Comparative Water Policies and Laws \\ University of South Australia
}

$\mathrm{T}$ The Australian Government has embarked on two phases of ambitious reform of state laws and policies for water management. The first in 1994 was known as Council of Australian Government reforms (CoAG) and the second in 2004 is known as the National Water Initiative reforms. These were prompted by a number of domestic environmental and social issues and international processes targeted at reducing government activity in water management. The first set required massive changes to water governance that is separating functions into environmental, economic, and water supplier and also requiring Environmentally Sustainable Development (ESD) and integration in all water development proposals. The second phase extends the first but is much more prescriptive and sets out 80 goals that water supply businesses and state governments must encourage rural and urban communities to achieve.

This paper presents empirical data of the results of telephone interviews with 183 Chief Executive Officers of the major water supply businesses in Australia. These respondents are highly educated and experienced business professionals. Bearing this in mind, the instrument designed for them required sophisticated responses to approximately 100 questions about Environmentally Sustainable Development, integration, and other issues about water policy changes under CoAG and to a lesser extent the National Water Initiative. The interviews were conducted between late September 2005 and late January 2006. This paper will report on responses to questions about integration and Environmentally Sustainable Development in water policy. For the Environmentally Sustainable Development questions, respondents were simultaneously emailed response sets so they could provide their view of the rank or order of the specified issues.

\section{Paradigms in Australian Water Policy Development}

Australia has had four paradigms of formal water resources laws and policies since 1788 (Figure 1). Prior to 1788 there is evidence that indigenous society engaged in regional sharing of parts of river and coastal systems in a complex social arrangement (Langdon 2002, McKay 2002a, 2002b, 2003). The imposition of the legal rule of Terra Nullius from 1788 and the deeming that there were no pre-existing laws meant that the common law of England was applied to the colony. This meant the riparian rule applied for surface water, thus limiting access to landholders by the river. In addition, the unimpeded extraction of ground water rule applied.

Development preceded apace in Paradigm 1 and the riparian rule was replaced in each State by a more extensive water allocation system, relying on channels and distributing water to users away from the main channel (Clark and Renard 1970, McKay 2006). Briefly, Paradigm 1 allocated surface water as if it would never run out and did not consider soil issues. The use of ground water was not regulated (following the common law rule). In this Paradigm, the States federated in 1901, but only on the condition that Section 100 of the Constitution preserved the rights of the States to control the conservation of water and its use for irrigation. This section ensured that federal power over navigation would be subordinate to these uses as long as the use was reasonable. The predominant 


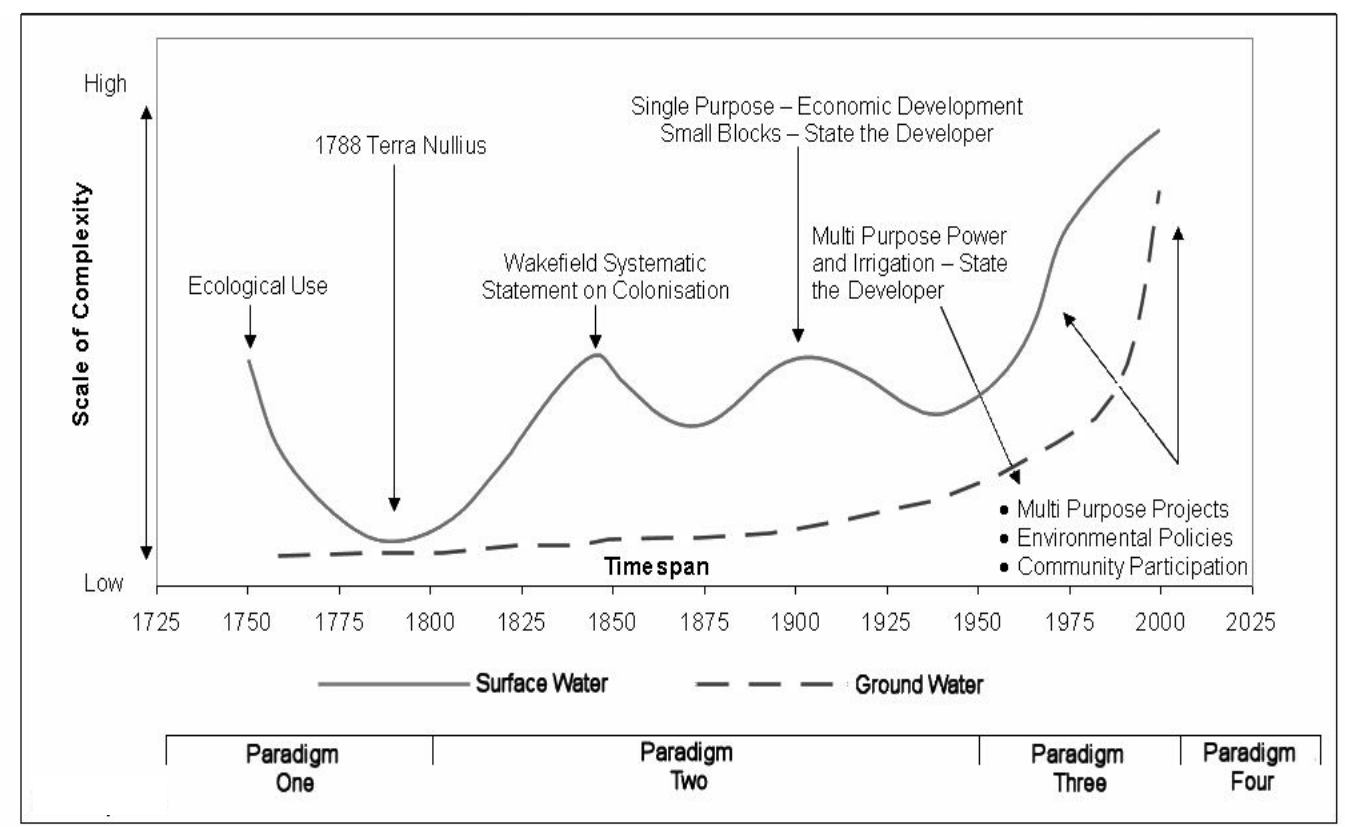

Figure 1. The four paradigms in Australian surface and ground water management.

approach was represented by the mantra "populate or perish" under the incentive of "turning water into gold” (Powell 1999, Sinclair 2001).

Paradigm 2 was characterized by large State works and schemes and some federal funding of these and funding of works on the basis of special issues in a State such as flood control, irrigation works, and salinity on the Murray (Hallows and Thompson 1999). Large dam storage in 1901 amounted only to $249 \mathrm{GL}$ (Gigaliters or $10^{9}$ liters) but, by 1950, it had increased to 9,509 GL and by 1990 to 78,919 GL (Broughton, 1999). A third of this storage is in New South Wales and another third is in Tasmania (essentially for hydropower generation). Most of the additions to storage occurred during 1960-79 because it was during this period that dams, with a total capacity of 50,000 GL, were constructed (Broughton, 1999).

Despite section 100, the Commonwealth has intervened in State water management through Sections 81 and 96 of the Constitution which gives the Commonwealth power to grant financial assistance to the States and impose conditions. In this context, the emergence of salinity problems was identified as a key issue, especially along the River Murray. In 1978, the Commonwealth passed the National Water Resources Financial Assistance Act which funded a broad range of works aiming to conserve water and mitigate salinity and floods, particularly in the Murray-Darling Basin (see Murray-Darling Basin Commission 2006). The great Artesian Basin Rehabilitation Program cofunded by the Commonwealth and three States , was started in 1989 to cap bores and hence stop depletion. The Federal Government also intervened using the trade and commerce power and external affairs power under section 51 to prevent the Crown in right of Tasmania from building a dam in 1983 (Commonwealth $v$ Tasmania 1983). More recently, these powers have been used to pass the Commonwealth Environmental Protection and Biodiversity Act by incorporating provisions of the Ramsar Convention on wetlands into the Act. Hence this phase is characterized by uncoordinated issue-driven intervention of the federal government in water management issues.

Paradigm 3 from 1994 represents the Federal government imposing more structured general reform targets on the States. The federal government's stake in Australia's water affairs changed significantly with the incorporation of water management into the CoAG competition framework. National competition policy, which included the part or full sale of several public enterprises, created a pool of funds by which each state could be "encouraged" to follow 
national water protocols. The reforms of 1994 have thus created much change and resulted in the restructuring of water management in each state. The reforms insisted that each state ensure that future water projects were based on ESD principles in conjunction with much more private sector participation and community involvement in water planning at a regional level.

Despite these initiatives, in 2000 the National Water Audit assessed that one-quarter of the surface water management areas and over onethird of the ground water management areas were at a high level of development and approaching or beyond sustainable extraction limits (Australian Water Resources Assessment 2000, Evans 2001, and Jones et al. 2001). This assessment of the regional pattern of water development is based on a broad definition of "sustainable flow/yield." The definition adopted by the Audit is based not just on physical aspects but also on economic, social, and environmental considerations including water quality and salinity. Paradigm 3 is hence characterized by introspective institutional reform in each state and the imposition of specific policies such as water markets in the context of ESD.

Paradigm 4 dated from June 2004 with the initiation of the National Water Initiative and extends and develops Paradigm 3's objectives. Paradigm 4 is characterized by the 80 national protocols on water planning processes and regional water planning documents as a key to achieve integration and ESD. The Australian Government acknowledges that efficient and more productive water use will become increasingly important over the coming decades as water issues impact upon the continued stability of Australia's rural sector, urban communities and the nation's economic well-being. The Government is determined to continue increasing efficiency in water use and implementing reforms to achieve this national objective (Department of Agriculture, Fisheries and Forestry 2006). Paradigm 3 and 4 are the focus of this paper and are detailed below.

This paper examines the perceptions, knowledge, and understandings of ESD by key front line people in the water community, namely the CEOs of 183 water supply businesses. The method was to identify the relevant policies and laws from state and federal instruments and from these identify the behavioral changes required. The next step was to design an instrument to evaluate (on an eleven point Likert scale) perceptions, understandings, and attitudes to the policies and laws by the key actors. The responses can then be used to evaluate the efficacy of the policies and laws and suggest reform proposals or different approaches to achieve the aims. Sometimes an approach is identified because respondents in different age groups respond differently (Hurlimann and McKay 2003). This approach is part of the general evidencebased policy movement, but consists of bottom-up subsets called Evaluation by policy implementers and Evaluation of law by implementers.

\section{Increasing Fiscal Federalism to Drive ESD in Australian Water Laws and Policies since 1994}

The 1994 reforms required a number of outcomes:

- Markets for water entitlements to improve efficiency

- Full cost recovery

- Two-part water tariffs (adopted in urban areas in 1998 and rural areas in 2001)

- Separate identification and funding of community-service obligations

- Allocation of water for environmental and social needs

- Principle of subsidiarity, i.e. management of resources at level closest to user.

This Paradigm was prompted by international movements toward corporatization of water authorities known as competition reforms (Saleth and Dinar 2004), by the 1990 Ecologically Sustainable Development process for nine specific industry sectors, driven in part by the UN Commission on Environment and Development (the Brundtland Commission) (Brundtland 1987), and by community reactions to large dams and environmental degradation of land and water, such as the Mabo decision in 1990 (Mabo v State of Queensland) which rebutted Terra Nullius. There is a much broader discussion of this in McKay $2002 \mathrm{a}$ and $\mathrm{b}$ and 2005. The 1994 goals provided a starting point for reform.

This paper deals with the perceptions of the CEOs in 2005/6, hence it covers Paradigms 3 and 
4. Paradigm 4 (which commenced in June 2004 with the National Water Initiaitve) is much more specific in its requirements on each state (NWI web site). The NWI was motivated by a number of factors and, in particular, issues 0such as the lack of cross-jurisdictional uniformity of policy instruments. For example, in the southern Murray system there were over 200 water license types (Shi 2005). A further motivating factor was the dearth of recycled water schemes (McKay and Hurlimann 2003).

\section{Commonwealth Organizational Structure in Water Reforms}

The Department of Agriculture Fisheries and Forestry (DAFF) in the capital of Canberra is responsible for improving the natural resource base-soil, vegetation, water and fisherieson which Australia's primary industries rely. It administers 10 acts that directly impact on ESD (Department of Agriculture Fisheries and Forestry 2002/3). DAFF aims to develop national initiatives to address issues relating to managing and using sustainable resources. The Natural Resource Management Team in DAFF manages the integrated implementation of Australia's two biggest natural resource management and conservation programs - the $\$ 1.4$ billion National Action Plan on Salinity and Water Quality and the \$3 billion Natural Heritage Trust. The Natural Resource Management Team is a joint venture between two Australian Government Departments of DAFF Environment and Heritage. The DAFF budget for Natural Resources Management Teams is less than 10 percent of this with the bulk going to Quarantine (Department of Agriculture Fisheries and Forestry 2006b). The Natural Resource Management Team is responsible for managing the Natural Heritage Trust and its local grant program, the Envirofund, as well as the National Action Plan and the Community Water Grants component of the Australian Government Water Fund. Australia's federal government (the Australian Government), and the state and territory governments work together on implementing both programs.

The Water Policy and Murray-Darling Basin Branch of DAFF (Department of Agriculture Fisheries and Forestry-Murray-Darling Basin Commission Branch 2006) also contribute to the Australian Government's development and implementation of national water policy reforms in the 70 percent of water used in agriculture. The branch helps implement the National Water Initiative to improve water management arrangements of benefit to the national economy. It also works with state governments to manage common water resources in the Murray-Darling Basin and the Great Artesian Basin. (Department of Agriculture Fisheries and Forestry 2006a). A key new additional aim is the promotion of sound natural resources management practices at a catchment or regional level (Department of Agriculture Fisheries and Forestry 2006b). This has encouraged the states to form in total 60 or so Natural Resource Management Boards at a regional scale as discussed below.

The six basics of national water reform under the National Water Initiative are:

1. Conversion of existing water rights into secure and tradable water access entitlements;

2. Completion of water plans that are consistent with the National Water Initiative through transparent processes and best available science;

3. Implementation of these plans to achieve sustainable levels of water extraction in practice;

4. Establishment of open and low cost water trading arrangements;

5. Improvements of water pricing to support the wider reform agenda; and

6. Implementation of national water accounting and measurement standards and adequate systems for measuring, metering and monitoring, and reporting on water resources.

The aims are also stated in this way to:

- improve the security of water entitlements, including clear assignment of risks of reductions in future water availability and returning over- allocated systems to sustainable allocation levels

- ensure ecosystem health by implementing regimes to protect environmental assets at the basin, aquifer, or catchment scale 
- $\quad$ ensure water is put to best use by encouraging the expansion of water markets and trading across and between districts and states where water systems are physically shared, involving clear rules for trading, robust water accounting arrangements, and pricing based on full cost recovery principles, and

- encouraging water conservation in our cities including better use of storm water and recycled water.

A key component of the National Water Initiative is more sophisticated and comprehensive water planning that deals with key issues such as the major interception of water, interaction between surface and ground water systems, and the provision of water to meet specific environmental outcomes. This planning process is the main characteristic of Paradigm 4 and its requirements to involve stakeholders in the planning process. As such the National Water Initiative has begun to allocate funding to community groups and State governments and drives the agenda by requiring each State to prepare implementation plans. Just under half of the National Water Initiative's 80 or so actions involve national actions or other action by governments working together. This reflects not just the emphasis on greater national compatibility in the way Australia measures, plans for, prices, and trades water. It also represents a greater level of cooperation between governments to achieve this end. This process will be driven by the new National Water Commission and \$2 billion over 6 years to be invested through the Australian Water Fund. As at July 2006, 33 projects have been approved spending $\$ 416$ million from the Australian Government Water Fund. The 2006/ 7 budget invested $\$ 500$ million in the iconic MurrayDarling river system. This money will be used to recover 500 Giga-liters of water for the environment under the Living Murray Scheme.

The National Water Commission is established under Australian Government legislation (i.e. the National Water Commission Act 2004). It is an independent statutory authority reporting to the Prime Minister and, on some water reform matters, through the Prime Minister to the CoAG. The Commission consists of seven Commissioners -four (including the chairman) nominated by the Australian Government, and three nominated jointly by the states and territories. Unique among Australian intergovernmental institutions, Commissioners are appointed for their expertise in a range of water-related fields (including freshwater ecology, hydrology, resource economics, and public sector management) rather than as representatives of sectoral or government interests. The Commission is supported by a small staff of just over 40. The National Water Commission has

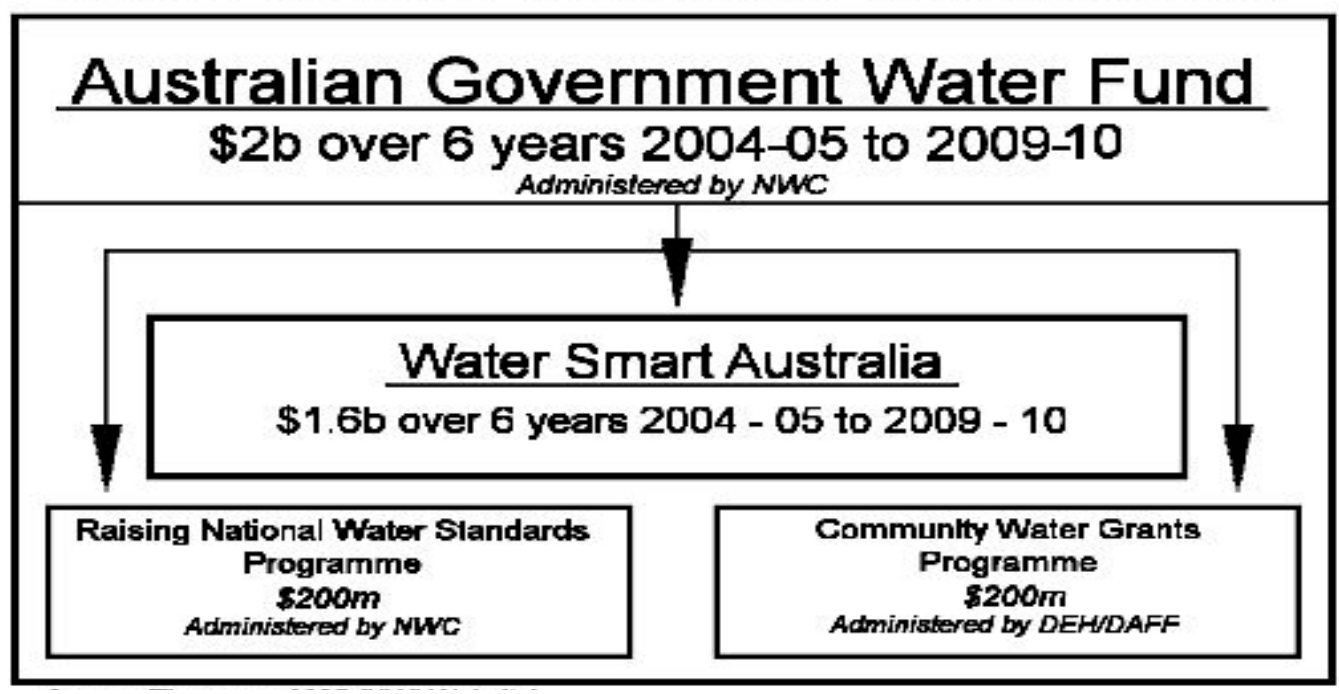

Figure 2. The Australian Government Water Fund (AGWF). Source: Thompson 2005 (NWI Website) 
three main functions:

1. assess governments' progress in implementing the National Water Initiative (e.g. through biennial assessments of progress commencing in 2006-07);

2. help governments to implement the National Water Initiative (e.g. by acting as lead facilitator on certain actions under the National Water Initiative such as nationally compatible registers of water entitlements and trades, and nationally consistent approaches to pricing); and

3. administer two programs under the Australian Government Water Fund (including recommending projects for decision by the Australian Government on financial assistance from the Water Smart Australia program and the Raising National Water Standards program. (Figure 2)

Clear Specification of Water Access Entitlements. Separation of land title and water title has been pursued by state and territory governments since the 1994 CoAG water reform framework. The National Water Initiative further specifies that consumptive use of water requires a water access entitlement to be described in legislation as a perpetual share of the consumptive pool of a water resource (paragraph 28). It also specifies the characteristics that water access entitlements should have (paragraph 31), including that they be exclusive, tradable, are able to be subdivided or amalgamated; are able to be mortgaged to access finance, and are recorded in public water registers. In most states and territories, the conversion of existing water entitlements into share-based entitlements as required under the National Water Initiative is still underway. For example, in Queensland and New South Wales, conversion of entitlements is occurring only when water plans are completed for catchments and ground water management areas; these water plans establish the available consumptive pool of the water resource. The National Water Initiative also requires that water provided to meet environmental and other public benefits is to have statutory recognition, and have at least the same degree of security as water access entitlements for consumptive use (paragraph 35). This is to ensure that water for environmental outcomes is not made less secure in the wake of greater security for consumptive water entitlements.

Water Accounting. Along with secure property rights, most market-based instruments require an agreed standard of measuring the commodity as a precondition for their operation. Most states are currently in the process of expanding metering of water used for irrigation. Australia has almost universal metering of water used in residential and business settings in major metropolitan areas. Adequate metering practices and accounting systems for water are, of course, necessary for

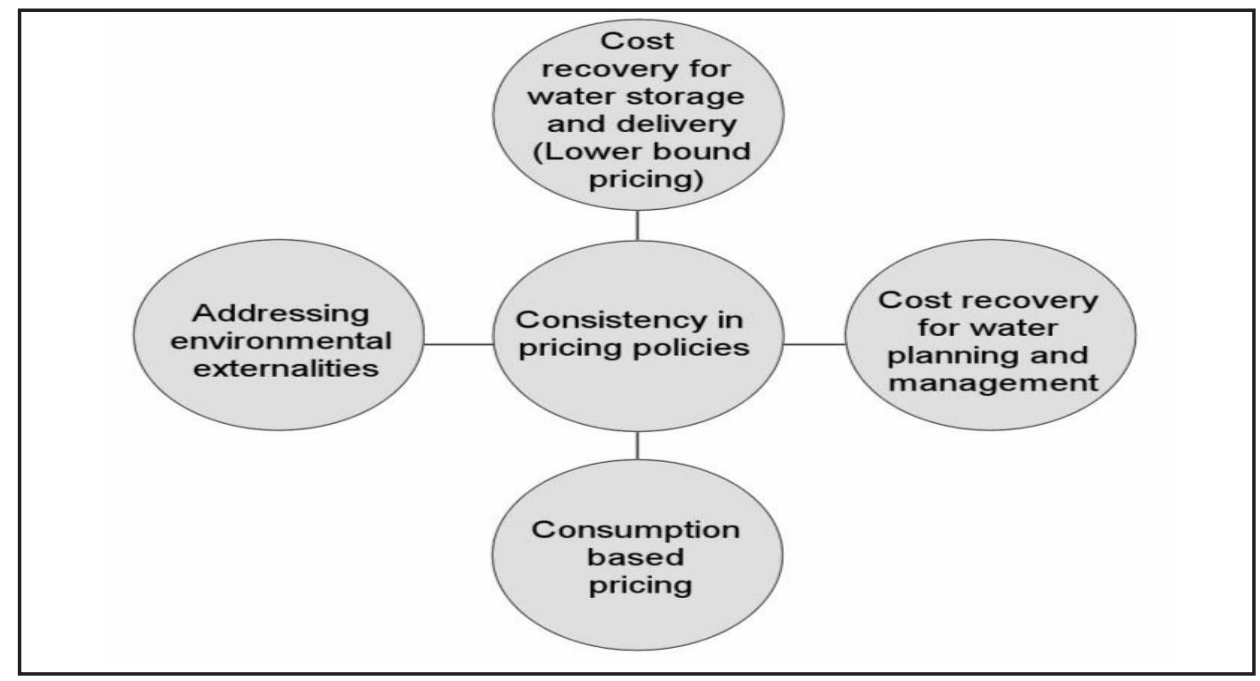

Figure 3. Elements of water pricing reform. 
effective charging for water use, and to support water trading (e.g. to ensure that water that is traded is available to be traded and is delivered to the buyer, and that information about water trades is made available to inform the market). Less sophisticated measurement and monitoring of water may be entirely appropriate in catchments where the resource is relatively undeveloped and there are few production pressures. In such cases the need to improve monitoring is driven by the need to better understand the resource so as to better manage its environmental values.

Clear Assignment of Risk for Changes in Water Allocation. As noted above, the creation of sharebased water access entitlements establishes a secure right to access the water resource. In the National Water Initiative, governments have also committed to establish a level of security around the size of the consumptive pool of water that entitlement holders can access. To this end, the National Water Initiative establishes a framework for assigning the risks of future reductions in the availability of water for consumptive use (paragraphs 46-51).

Efficient Water Markets. At present, there are a range of institutional barriers to the trade of permanent water entitlements out of many irrigation districts in Australia - either in the form of trading rules, policies governing public irrigation authorities, or policies contained in the memoranda and articles of association of some private irrigation corporations (notably in New South Wales). Governments - including those in the southern Murray Darling Basin (New South Wales, Victoria, and South Australia) - are taking steps to free up water trades from their irrigation areas to other higher value users. Initially, trades from each irrigation area are intended to be enabled for up to four percent of each area's total water entitlement. This measured step is provided in the National Water Initiative in order to help manage concerns about the adjustment of regions to trade, and to enable the National Water Commission to monitor the socio-economic impacts of trade. Expansion of water trade will also rely heavily on reducing the transaction costs of trades. In particular, the National Water Initiative requires compatible water registers between states and other compatible institutional arrangements in order to enhance trading opportunities.

Improved Water Pricing Policies. There have been significant improvements in water pricing arrangements since the 1994 CoAG water reform framework. These include:

- institutional separation of water service providers (e.g. urban and rural water suppliers) from water regulation and planning bodies;

- establishment of independent bodies for reviewing water pricing or price-setting processes in every state and territory; and

- A move to consumption-based pricing aimed at full cost recovery in almost all major metropolitan centers.

Governments have committed to continue with pricing reform, in particular:

- to continue movement to pricing that recovers the full costs of water storage and delivery for rural and regional systems;

- to continue movement to pricing that achieves a commercial return on assets (while avoiding monopoly rents) for metropolitan, rural, and regional water storage and delivery;

- $\quad$ pricing that recovers a proportion of the costs of water resource management and planning cost recovery for such activities to manage the consequences of commercial water extraction has become a legitimate proxy for more direct externality pricing in rural areas;

- nationally consistent benchmark reporting on the service quality and pricing of all water service providers; and

- moving towards more nationally consistent approaches to pricing across all these.

Water pricing reform is currently a very active area for most state and territory governments. The overall intent is to ensure that prices set by mechanisms other than the market (i.e. by governments, public/private water service providers, and/or independent pricing bodies) do not lead to perverse outcomes either in secondary water markets, or for water-related investment activity. This is critical to facilitating market based instruments as more prominent mechanisms for managing water in Australia. 


\section{State Implementation of the NWI through Regional Organizations}

Regional delivery of natural resources management is the principle mode of investment under the Natural Heritage Trust and National Action Plan for salinity and the particular role of DEH through its leadership of the Natural Heritage Trust second Phase. Each State needs to create new regional Natural Resources Management structures. Such bodies should include landowners, industries, non-government organizations, indigenous representatives, representatives from the three levels of government (local, state, and national) and other interested people. This is the way for local and other parties to be involved in natural resources management (Australian Local Government Association 2005). Australia has been divided into 60 regions with each one responsible for preparing a regional natural resources management plan. The structure and nomenclature varies between and within the states based on variations in state legislation (Mutton pers. com. 2006 SA). The selection processes for members of the regional bodies differ as well. The final aspect of difference is where the state overarching body is placed in the existing state natural resources management processes. The case study from South Australia sets out the process in a well advanced state. The role of the Natural Resources Management Council in South Australia under the Natural Resources Management Act 2004 is to draft a State Plan for natural resources management and to take responsibility to deliver the National Action Plan and Natural Heritage Trust bilateral Agreements signed with the Federal Government. The State Plan is for 5 years and was completed in 2005 with a 50 -year vision. The Plan informs government agencies, the eight regional Natural Resources Management Boards, local government, community and industry partners (Eyre Peninsula Coastal Development Strategy 2006). Each Regional Natural Resources Management Board drafts their own Regional Plan involving all of the above with support from State Agencies. Each Regional Plan highlights all the natural resources management issues in the region, develops actions to address these concerns and then selects the most important issues for action. The plans also set resource conditions and management action targets based on agreed national standards to help determine progress toward achieving outcomes.

\section{State-Based Definitions of Environmentally Sustainable Development and Natural Resources Management: Potential Partnership Problems for Water Supply Businesses}

While the overarching goals are set federally, the means to achieve them are left to the states who, as in all federations, chose to do things differently. This can create a laboratory of policy experiments that offer learning opportunities, but can also create confusion (Brandies 1932). What does sustainable development really mean? Sustainable development as a concept is notable for the lack of consistency in its interpretation (Sharachchandra 1991). While its breadth is appealing on the political level, this is also its weakness as the problems of poverty, environmental degradation, economic growth, and participation are not well articulated. Such a lack of clarity may hamper the debate and certainly the implementation.

In Australia, each state has defined Environmentally Sustainable Development in a number of acts that apply to all actions of the water supply businesses and other institutions. The definitions of each of these spans over many sections of each of the Acts and the rules and interpretation of Acts in each state are also different. The modern concept of Environmentally Sustainable Development, which in some instances date from only 1987 (Brundtland 1987), differs in its width within each state (Table 1). The fundamental premise of Environmentally Sustainable Development (ESD) is that economic development must be balanced against the protection of biological diversity, the promotion of equity within and between generations, and the maintenance of essential ecological processes. The Commonwealth Government working groups on ESD drafted these principles as a guide in 1992 (Hamilton and Throsby 1998) to facilitate decisionmaking processes to effectively integrate both long and short-term economic, environmental, social, and equity considerations.

1. Lack of full scientific certainty should not be used as a reason for postponing measures to prevent environmental degradation (the 
Table 1. Relative ranking of width of ESD definition in four Australian states and through MBDC template legislation in each state ${ }^{1}$.

\begin{tabular}{ll}
\hline \multicolumn{2}{c}{ Rank of ESD definitions width } \\
\hline MDBC Template* & 1 (Equal) \\
SA (downstream) 10\% in MDB area & 1 (Equal) \\
Qid (up stream) 25\% in MDB area & 2 \\
MSW (up stream) 90\% in MDBC area & 3 \\
VIC (midstream) 60\% in MDb area & 4 \\
\hline
\end{tabular}

*legislation inserted into state law of Queensland, New South Wales, Vic, SA

Precautionary Principle).

2. The global dimension of environmental impacts of actions should be recognized and considered.

3. The need to develop a strong, growing and diversified economy that can enhance the capacity for environmental protection should be recognized.

4. The need to enhance and maintain international competitiveness in an environmentally sound manner should be recognized.

5. Decision-making processes should effectively integrate both long and short-term economic, environmental, social, and equity considerations.

6. Cost-effective and flexible policy instruments should be adopted.

7. Broad community involvement should be facilitated.

This statement has been accepted by CoAG and reflects that economic efficiency is not the main goal of water institutions but rather that there is a need to achieve ESD and balance between the social, economic, and environmental needs. These principles have accordingly guided the collective thinking of governments in the formulation of contemporary water policy. Integration is required, especially under Paradigm 4, but is mentioned in an ad hoc way by all the states. The CEOs were asked questions about their perceptions of the integration of the policy processes in water reform and some of these results are reported here.

\section{CEOs of Water Supply Businesses as Key Actors in Achievement of Environmentally Sustainable Development}

The obligations to achieve Environmentally Sustainable Development are imposed on all CEOs of the water supply businesses by a number of State laws and also through the implementation of the bilateral Natural Heritage Trust and National Action Plan agreements with the Federal Government. There are 333 major water supply businesses in Australia (Table 2) and these are distributed over 14 different types of legal organizational forms. Previous international research has described how organization form has a great influence on the achievement of policy (North 1990). These range from government-owned corporations, private companies, local government authorities, to water boards. Many have their own act or rely on powers in another act.

Once we identified the types, we arranged to interview a sample of the CEOs according to the typology type. The CEOs were distributed as such; 86 out of 115 from Queensland, 38 from 78 in New South Wales, 24 from 29 in Tasmania, 13 from 24 in Victoria, 20 from 22 in Western Australia and the only one from each of the Australian Capital Territory and Northern Territory. The distribution by typology type reflected the proportions, with local government predominating.

\section{Responses of CEOs to Environmentally Sustainable Development and the Paradigm 3 and 4 Water Reforms}

Following the approach described above, this work sought to perform an Evaluation by policy implementers and Evaluation of law by implementers. The CEOs were interviewed over the phone after a time had been made for them to have 30 minutes free to do the interview. The interviews took place between September 2006 and January 2006 and were conducted by three trained professional interviewers at Ehrenberg Bass Institute. The respondents were all sent a project information sheet and advised that their responses were confidential. There were over 100 questions and the average time for each interview was 27 minutes with no one stopping the interview. Respondents reported that they liked the survey as they had a chance to explore issues and report on 
Table 2. Corporate governance legal types (typologies) of major WSB.

\begin{tabular}{lccccccccc}
\hline & ACT & NSW & NT & QLD & SA & TAS & VIC & WA & Total \\
\hline Local Government Regional Council (LGRC) & 0 & 2 & 0 & 0 & 0 & 0 & 0 & 0 & 2 \\
Shire Council (LGSC) & 0 & 46 & 0 & 92 & 0 & 17 & 0 & 14 & 169 \\
City/Council (LGCC) & 0 & 0 & 0 & 15 & 0 & 5 & 0 & 0 & 20 \\
Local Government Owned corporations (LGOC) & 0 & 14 & 0 & 4 & 0 & 0 & 0 & 0 & 18 \\
Joint Local Government Organization (JLGG) & 0 & 5 & 0 & 1 & 0 & 3 & 0 & 0 & 9 \\
Water Board [includes Rural and Water Drainage] & 0 & 0 & 0 & 0 & 0 & 0 & 0 & 2 & 2 \\
Government Departments Licenser (GD) & 0 & 0 & 0 & 1 & 0 & 2 & 0 & 0 & 3 \\
Government Owned Corporation (GOC) & 1 & 5 & 1 & 1 & 1 & 0 & 6 & 1 & 16 \\
Statutory Bodies (SB) & 0 & 0 & 0 & 0 & 0 & 0 & 18 & 0 & 18 \\
Corporation Law Companies (CLC) & 0 & 3 & 0 & 1 & 2 & 0 & 0 & 1 & 7 \\
Irrigation Trusts (IT) & 0 & 2 & 0 & 0 & 4 & 0 & 0 & 0 & 6 \\
Undetermined & 0 & 0 & 0 & 0 & 0 & 2 & 0 & 4 & 6 \\
Hybrid - (SB/CLC) & 0 & 1 & 0 & 0 & 0 & 0 & 0 & 0 & 1 \\
Hybird - (IT/CLC) & 0 & 1 & 0 & 0 & 0 & 0 & 0 & 0 & 1 \\
Total & 1 & $74-79$ & 1 & 115 & 7 & 29 & 24 & 22 & 278 \\
\hline
\end{tabular}

Source: 183 CEO Surveys CRF-IF006

Table 3. Number of survey respondents by state and typology.

\begin{tabular}{|c|c|c|c|c|c|c|c|c|c|c|c|}
\hline & CLG & GD & GOC & JLGG & LGCC & LGOC & LGRC & LGSC & SB & UND & WB \\
\hline ACT (1) & - & - & 1 & - & - & - & - & - & - & - & - \\
\hline NSW (38) & - & - & - & - & 4 & 1 & 2 & 31 & - & - & - \\
\hline NT (1) & - & - & 1 & - & - & - & - & - & - & - & - \\
\hline QLD (86) & - & 1 & - & - & 13 & 1 & - & 71 & - & - & - \\
\hline TAS (24) & - & - & - & 3 & 5 & - & - & 14 & - & 2 & - \\
\hline VIC (13) & - & - & 3 & - & - & - & - & - & 10 & - & - \\
\hline \multirow[t]{2}{*}{ WA (20) } & 1 & - & 1 & - & - & - & - & 14 & - & 2 & 2 \\
\hline & 1 & 1 & 5 & 3 & 22 & 2 & 2 & 130 & 10 & 4 & 2 \\
\hline
\end{tabular}

issues that concerned them. The results for all but the first questions are reported by state (as there is only a single authority in the Australian Capital and Northern Territories, their responses will not be published to protect confidentiality) and corporate governance type. This section will present the responses to these 4 questions on Environmentally Sustainable Development.

1. Degree of effort put into each ESD principle

2. Difficulty in achieving ESD principles in their water supply businiesses

3. The ESD process is transparent

4. I am able to achieve sustainable water management

It will then present three questions on water policy and intergovernmental integration

1. There is a huge amount of trust between this organization and the state government.

2. This organization is nested in a mutually supportive state government policy environment.

3. All sectors of the community of this water business understand the viewpoint of others in this area.

\section{Environmentally Sustainable Development}

The first two questions reported here were 
Table 4. Difficulty in achieving and degree of effort put into each Environmentally Sustainable Development guiding principle.

\begin{tabular}{lcc}
\hline Criterion & $\begin{array}{c}\text { Difficulty in achieving } \\
\text { ESD principles }\end{array}$ & $\begin{array}{c}\text { Degree of effprt put into } \\
\text { each ESD principle }\end{array}$ \\
\hline $\begin{array}{l}\text { The global dimension of environmental impacts of } \\
\text { actions should be recognized and considered. }\end{array}$ & 896 & 728 \\
$\begin{array}{l}\text { Lack of scientific certainty should not be used } \\
\text { as a reason for postponing measures to prevent } \\
\text { environmental degradation (Precautionary Principle). }\end{array}$ & 624 & 1092 \\
$\begin{array}{l}\text { The need to develop a strong, growing, and diversified } \\
\text { economy, which can enhance the capacity for } \\
\text { environmental protection, should be recognized. }\end{array}$ & 795 & 714 \\
$\begin{array}{l}\text { The need to enhance and maintain international com- } \\
\text { petitiveness in an environmentally sound manner should } \\
\text { be recognized. }\end{array}$ & 772 & 1261 \\
$\begin{array}{l}\text { Decision-making processes should effectively integrate } \\
\text { both long and short-term economic, environmental, } \\
\text { social, and equity considerations. }\end{array}$ & 723 & 1234 \\
$\begin{array}{l}\text { Cost-effective and flexible policy instruments should be } \\
\text { adopted. }\end{array}$ & & 1232 \\
\begin{tabular}{l} 
Broad community involvement should be facilitated. \\
\hline
\end{tabular} & 424 & \\
\hline
\end{tabular}

emailed to the respondents so they could see the full text and they were asked to rate each one from 1 not at all difficult to 10 extremely difficult. In the second question, they were asked to rate them according to the effort they have put in from 1 least effort to 10 most effort. In all the questions 11 was don't know and refused but there were very few of these. The votes were then tallied. Responses to the first question indicate that the CEOs thought that it was most difficult to achieve global dimensions and least difficult to achieve broad community involvement (Table 4). In relation to effort, most effort went into the three dimensions of broad community involvement, cost effective policies, and integrated decision-making processes (Table 4). In relation to the transparency of the ESD process, most organizations have a neutral view (Table 4). All had heard of the process. Hence they are neutral as to whether the process in their state is transparent. The Water Boards perceive the process as transparent. Local governments are clearly of the neutral view (Figure 4). In relation to ability to achieve ESD, the local governments were most likely to be neutral, Water Boards and Government Owned Corporations were more likely to agree that they can achieve it (Figure 5). In relation to work on local government and participation in Regional Natural Resources Management Plan development, it was reported that most councils were not active because of a lack of resources with 56 percent of councils highlighting a lack of human or financial resources to effectively participate. Only 31 percent of councils believe they have a good or comprehensive capacity to develop and implement the regional plans (Australian Local Government Association 2005).

\section{Water Policy and Intergovernmental Integration}

Social capital theory in relation to environmental matters has often focussed on understanding how various actors interact with one another in relation to the water policy environment. By understanding the social capital of different environmental actors, for example water users and water policy implementers, we can understand why policies end up being implemented and why noble aims often fail. The question related to trust between the organization and the state government yielded results that differed markedly among the states. Water supply businesses in Victoria were most likely to trust and the lowest trust level was 


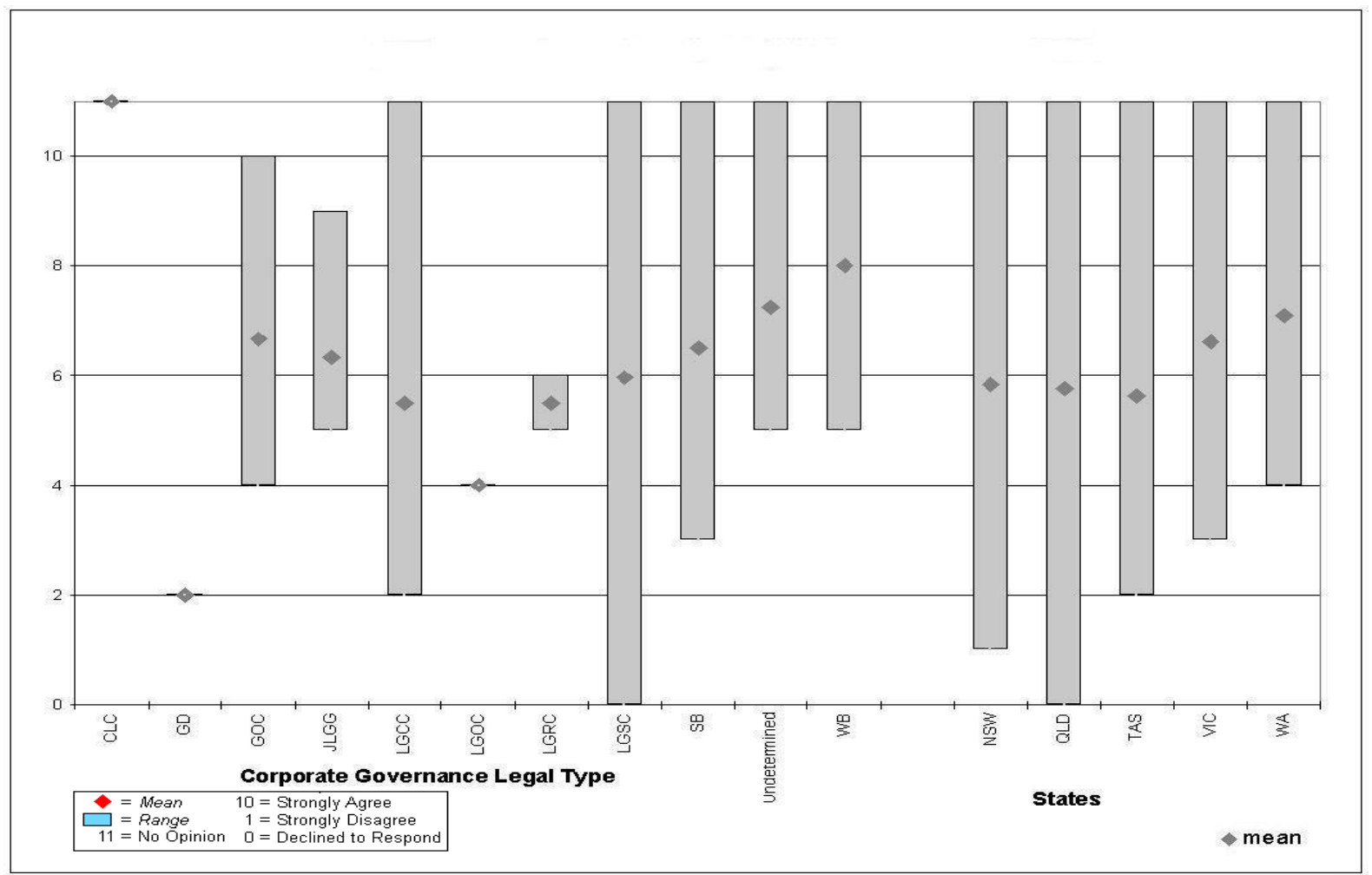

Figure 4. Qu. 26 - The ESD process is transparent.

Source: 183 CEO Surveys CRC-IF 2006

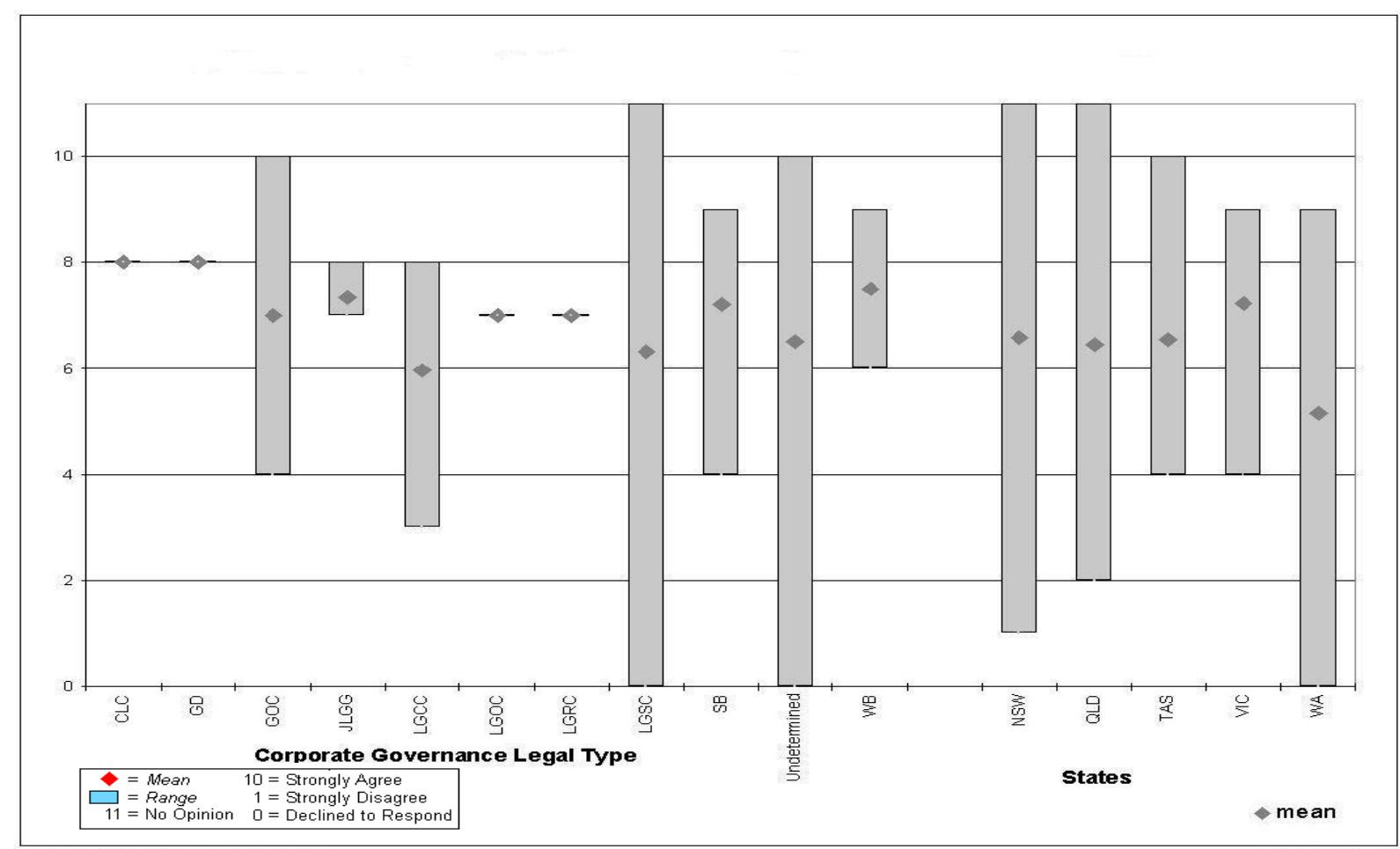

Figure 5. Qu. 7 - I am able to achieve sustainable water management. Source: 183 CEO Surveys CRC-IF 2006 
found in New South Wales. A study in Queensland of stakeholders in small catchments found that there was little trust in the state government over natural resources management (Rickson 2006). The CEO's also reported low levels of trust in relation to the relevant state government. There was also a massive variation between corporate governance types, as well with statutory boards, and government-owned corporations were most trusting and local government least (Figure 6). In support of the above, the CEO's also reported that they don't generally feel nested in a mutually supportive policy environment, except in Victoria, and this related directly to the corporate governance type of government-owned corporations (Figure 7). In relation to whether the CEOs feel that all sectors of their community understand the viewpoints of others, the results suggest that they are neutral, so they are not confident and this does not vary by state or corporate governance type. Despite all the effort to facilitate broad community involvement (Figure 2), the CEO's see little change in the mindset of the community (Figure 8).

\section{Summary and Conclusions}

There have been massive reforms of water laws, policies, and institutions over the last 12 years in Australia. Most reforms require partnerships between Commonwealth and state agencies and also partnerships between different sectors of the community to achieve Environmentally Sustainable Development (ESD) implementation. This paper has shown that while there has been considerable effort put in by the CEO's, the partnerships between sectors of the community, and between them and state governments, are impaired by a lack of trust and a perception that the water policies are not mutually supportive. Many of them are also puzzled as to how to achieve ESD and, with acute differences between the states in definitions, there is a limited scope to learn from each other. Finally, the CEO's still think that sectors of their community don't understand each other. However, the water reform is relatively new and

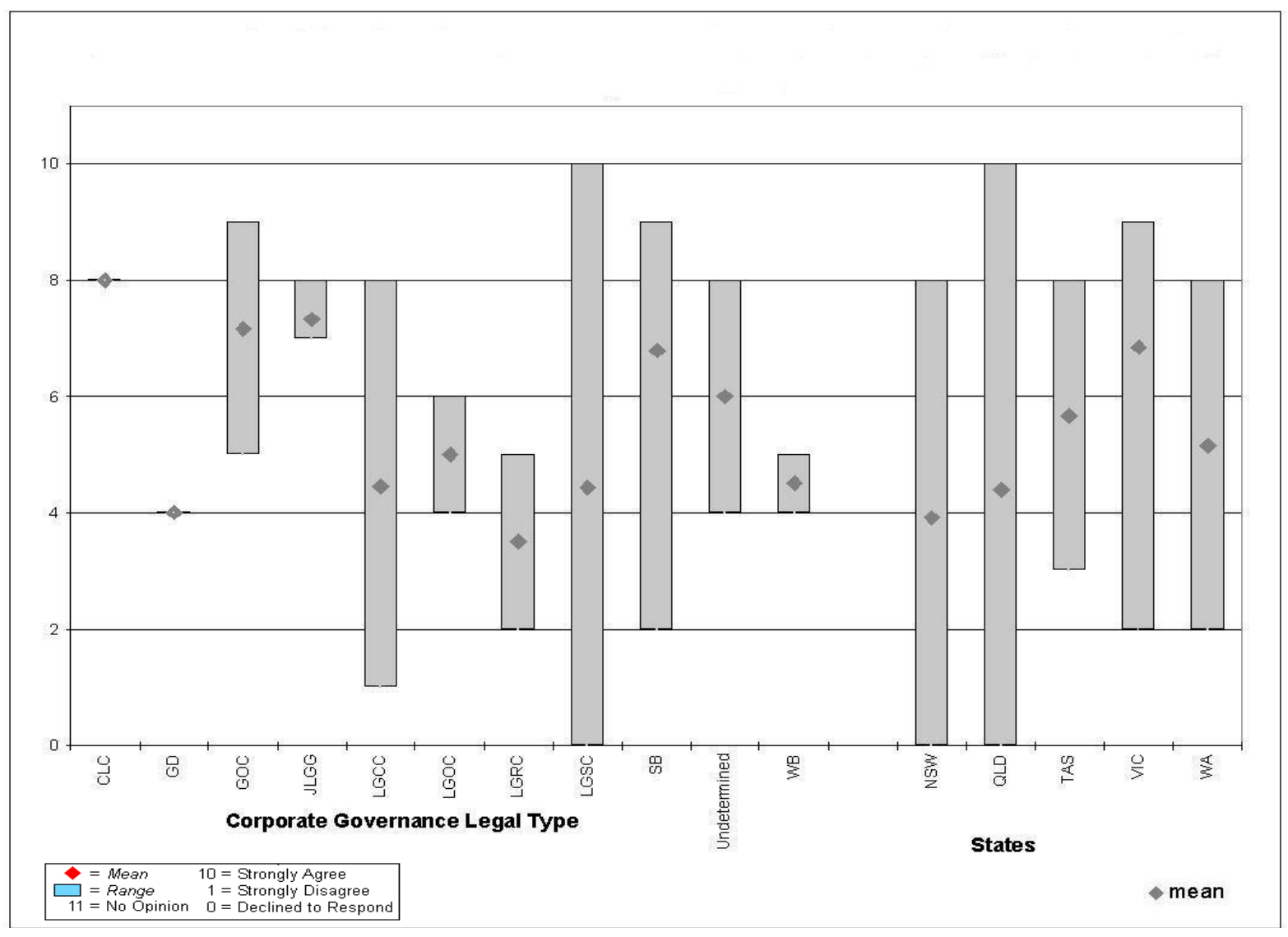

Figure 6. Qu. 91- There is a huge amount of trust between this organization and the state government. Source: 183 CEO Surveys CRC-IF 2006 


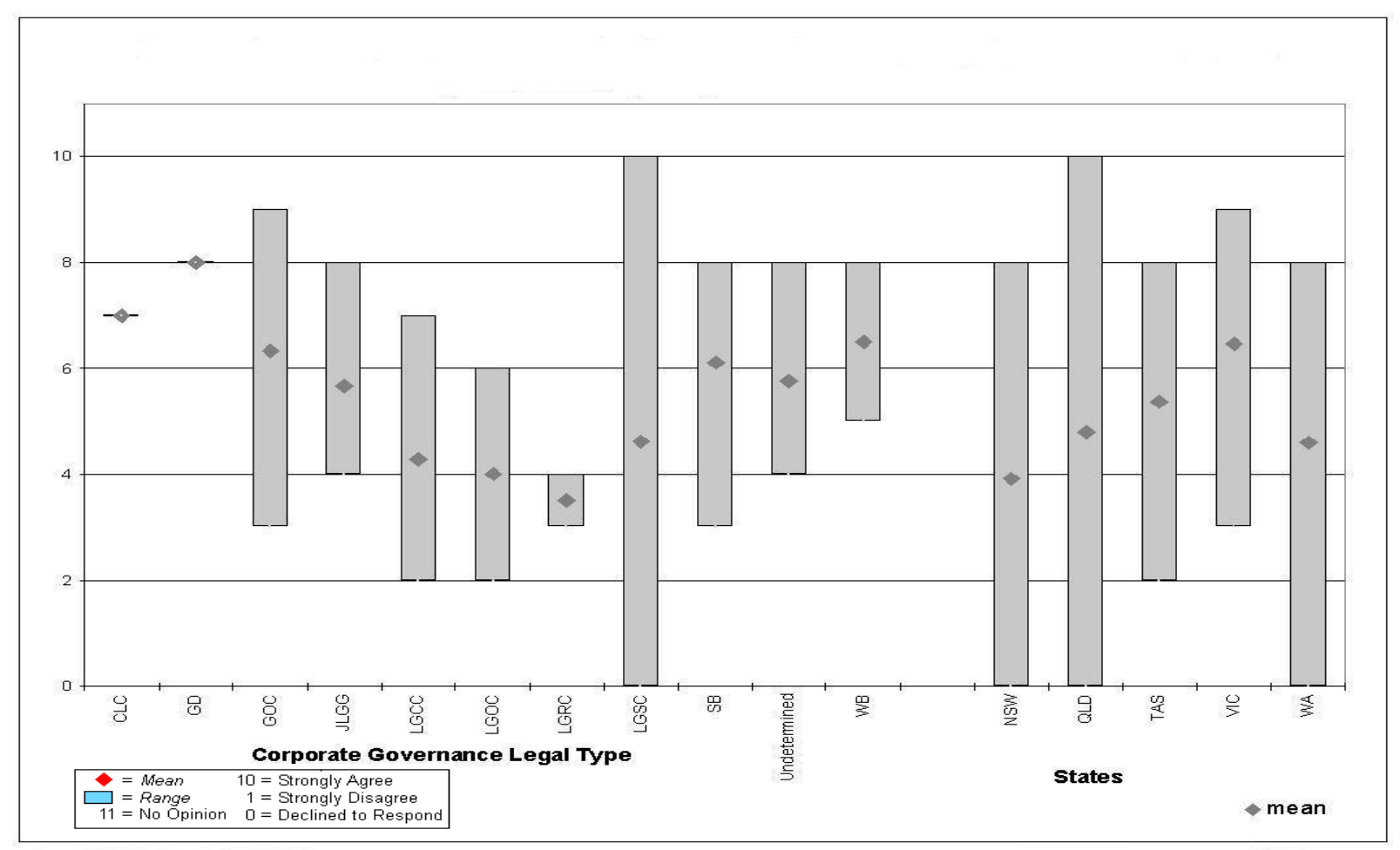

Figure 7. Qu.93- This organization is nested in a mutually supportive state government policy.

Source: 183 CEO Surveys CRC-IF 2006

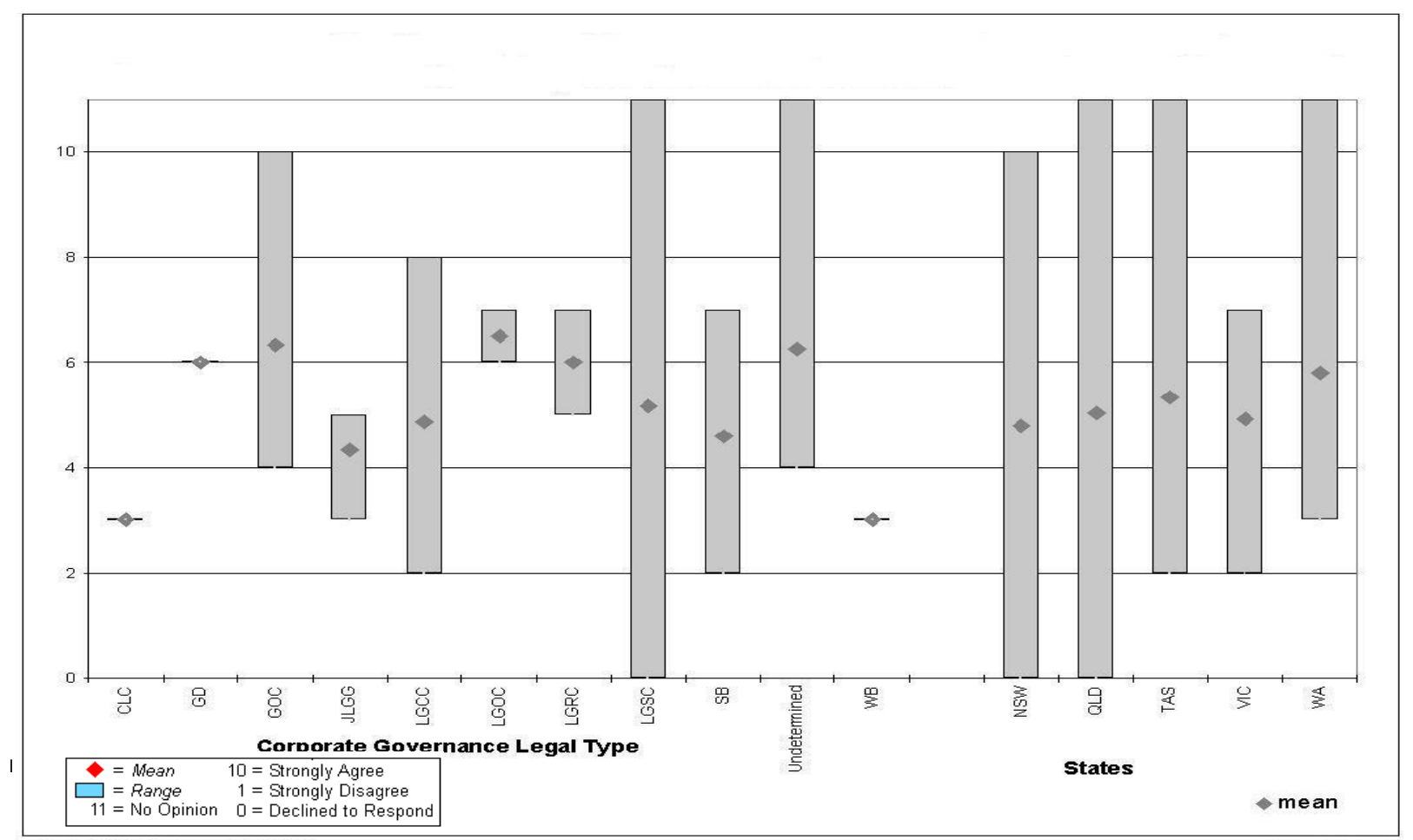

Figure 8. Qu.14- All sectors of the community of this water business understand the viewpoint of others in the area. Source: 183 CEO Surveys CRC-IF 2006 
indeed some of the 80 obligations in the National Water Initiative specifically address some of these issues, for example, the proposed lexicon of water management terms. With longer involvement in the reforms, the answers to these questions should change. That is, we would expect the CEO's responses to indicate a greater ability to achieve ESD. Perceptions of ability to achieve ESD will be linked to greater perception of transparency of the process, trust in the state government, and other factors.

\section{Acknowledgements}

This work was conducted as part of a project for the Cooperative Research Centre Irrigation Futures. It was supported in kind by members of the Cooperative Research Centre, especially Matthew Durack, Glen Starkey, John Bourne, Eddie Parr, Peter Smith, John Williams, Tom Vander Wel, and Bernadette Zerba. The project was also supported by the University of South Australia School of Commerce and benefited from feedback given by the respondents and also from comments by George Warne (New South Wales), Geoff Parish and Tony Thompson ((South Australia), and the opportunity to present some of this material to meetings organized by the Australian Centre for International Agricultural Research and the Australian National Committee on Irrigation and Drainage. Other support was made available from Jolyon Burnett, Irrigation Association of Australia, and Stephen Mills, Australian National Committee on Irrigation and Drainage and Chris Davis of the Australian Water Association. The Australian Centre for International Agricultural Research also supported this research through workshops on a current project that was initiated by Donna Brennan.

The project employed Adam Gray, who did a great job in liaising with many organizations and drawing the figures. Michael Griffin and Fiona Partington checked the typology by reference to the Annual reports of the water supply businesses. Kirsty Willis co-ordinated the interviewing with good humor despite this being one of the longest and technically challenging surveys in the EhrenbergBass Research Institute experience. Rex Jones and Kathryn Pickering provided much support in the financial management and other members of the
Centre collected articles and checked the results, especially Ganesh Keremane, Anna Hurlimann, Arthur Spassis, and Diwakara Halanaik.

\section{Author Bio and Contact Information}

Jennifer McKay is a Professor of Business Law at the University of South Australia. Her research interests concern water law reform and, in particular, regulatory models for the management and allocation of water between competing uses and between competing jurisdictions. Before working in academia and research, Professor McKay worked in major commercial law firms in Adelaide and Melbourne. Her areas of practice included trade practices, corporations law and environmental audits. She has been nominated by the Australian Branch of the International Law Association to be a member of the International Law Association committee on International Law on Sustainable Development www.ila-hq.org She is a Co-Founder and Director of the Centre for Comparative Water Policies $\&$ Laws. The Centre has international members from 20 countries including Sweden, Sri Lanka, Spain, USA, India, Finland and Israel. http://business.unisa.edu. au/commerce/waterpolicylaw/ Professor McKay is a key researcher for the Cooperative Research Centre for Irrigation Futures. This new centre aims to halve water use within Australia and define sustainable irrigation areas and practices. www.irrrigationfutures.org.au.

\section{Endnotes}

1. The Murray Darling Basin Agreement 1992 (as amended in 2000) is between the Commonwealth and the four States and aims to .. Promote and coordinate effective planning and management for the equitable efficient and sustainable use of water, land and environmental resources of the Murray Darling Basin.”

\section{References}

Australian Local Government Association. 2005. NRM Survey of Local Government 2004-5, Angela Shepherd http://www.alga.asn.au/policy. environment.nrm/survey.

Australian Water Resource Assessment. 2000. Surface and Groundwater Availability and Quality, a report of the National Land and Water Resources Audit (Audit).

Brandeis (Justice). 1932. New State Ice Co. $v$ Liebmann 285 US 262 AT 311.

Broughton, W. ed. 1999. A Century of Water Resources Development in Australia 1990-1999. The Institution of Engineers Australia Sydney. 
Brundtland Report. 1987. Our Common Future, Report of the UN World Commission on Environment and Development. Oxford University Press, Oxford.

Clark, S.D. and I.A. Renard. 1970. The riparian doctrine and Australian Legislation. 7 Melbourne University Law Review 475.

Department of Agriculture Fisheries and Forestry, 2002/3. National Government. Available at: http://www.daffa.gov.au/about/annualreport/0203/appendices/app6.

Department of Agriculture Fisheries and Forestry. 2006a. National Government. Available at: http://www.daffa.gov.au/natural-resources/water/ reform/resources.

Department of Agriculture Fisheries and Forestry. 2006b. General Government Sector budget statements. Available at: http://www.daffa.gov. au/__data/assets/pdf_file/5680/outcomes.pdf.

Department of Agriculture Fisheries and Forestry, Murray Darling Basin Commission 2006 MurrayDarling Basin. Available at: www.daffa.gov.au/ mdbc.

Evans, R. 2001 Managing Over-Allocated Groundwater Systems, Paper presented at the 3rd Australasian Natural Resources Law and Policy Conference, Adelaide p 194. A copy of the paper was obtained directly from Sinclair Knight Merz.

Government of South Australia and Eyre Peninsula Local Government Association. 2006. Eyre Peninsula Coastal Development Strategy.

Hallows, P. and D. Thompson. 1999. The History of Irrigation in Australia. Australian National Committee on Irrigation and Drainage, Canberra.

Harris, S and D. Throsby. 1997. The ESD Process: Background, implementation and aftermath. In Hamilton, C. and D. Throsby (eds.) The ESD Process: Evaluating a Policy Experiment, p 121, Academy of Social Sciences and Graduate Program in Public Policy Australian National University Workshop, ANU, Published by the Academy of Social Sciences in Australia and Graduate Program in public Policy, ANU.

Jones, G., J. Whittington, J. McKay, A. Arthington, I. Lawrence, S. Cartwright, and P. Cullen. 2001. Independent Assessment of Jurisdictional Reports on the Achievements of the COAG Water Reforms 2001, Cooperative Research Centre for Freshwater Ecology, funded by NHT, Environment Australia and National Competition Council, Canberra.
Langdon, M. 2002. Briefing Papers: Indigenous rights to waters, ATSIC.

McKay, J. M. 1994. Water planning in SA. Australasian Journal of Natural Resources Law and Policy, 1(2) 595-609.

McKay, J. M. 2002a. Encountering the South Australian Landscape: Early European misconceptions and our present water problems. Hawke Institute Working paper series paper 21. www.hawkecentre.unisa.edu. au/institute.

McKay, J. M. 2002b. Legal issues in water planning regimes: Lessons for Australia, in Brennan, D. (ed.), Water Policy Reform: Lessons from Asia and Australia. Australian Centre for International Agricultural Research, proceeding 106, pp 48-62 Canberra. ACIAR.

McKay, J. M. 2003. Marketisation in Australian freshwater and fisheries management regimes. In Dovers S and Sue Wild River (eds.), Managing Australia's Environment. Annandale Federation Press, pp. 363-390.

McKay, J. M. And A. Hurlimann. 2003. Attitudes to reclaimed water for domestic use; Age Part 1, Water, 28(5) 45-50.

McKay J. M. 2005. Water Institutional reforms in Australia. In Special issue of Water Policy Water Institutional reform: Theory and practice, $p$ 3553.

McKay, J. M. 2006. The legal framework of Australian water. In Crase L (Ed.) Water Resources in Australia, Issues in Water Policies Series, series editor A. Dinar, Resources for the Future, www. RFFPress.org/water.

Murray Darling Basin Commission. Available at: www.mdbc.gov.au.

Mutton, D. pers comm. Presiding member of the NRM Council SA.

National Water Initiative web site www.nwc.gov.au.

North, D. 1990. Institutions, Institutional Change and Economic Performance. Cambridge University Press, Cambridge, MA.

Powell, J. 1999. Victoria, in Broughton, W. (ed.), A Century of Water Resources Development. In Australia, The Institution of Engineers Australia, Sydney.

Rickson, S. 2006. Linking the social with the environmental: Identifying community capacity in the South East Queensland Western Catchments Group, In Whelan J. ( Ed.) Partnership Based Social Research for Sustainable Natural Resource 
Management in Queensland. National Action Plan for Salinity and Water Quality.

Saleth, R. M. and A. Dinar. 2004. The Institutional Economics of Water: A cross-country analysis of institutions and performance. Cheltenham, UK: Edward Elgar Publishing Pvt.

Sharachchandra. 1991. Sustainable Development: A critical Review. World Development 19 (6): 607621.

Shi, T. 2005. Simplifying complex water entitlements. Water 32 (5): 39-43.

Sinclair, P. 2001. The Murray: A River and Its People. Melbourne University Press. 